\section{Soviet reform of education}

\section{London}

THE Soviet Union is to amalgamate into a new State Committee for Public Education the three All-Union bodies with responsibility for education - the ministries for education and for higher and specialized education and the State Committee for Public Education. The retiring Higher Education Minister, G.A. Yagodin, will head the new state committee.

The objective, apart from the avoidance of job duplication and bureaucratic barriers as part of perestroika, appears to be closer coordination between secondary and tertiary education. Reform along similar lines in the Estonian republic was announced only a few months ago.

Concern has been growing among Soviet educationists about the gap between the educational attainments of school-leavers and the minimum requirements of universities and colleges in the tertiary sector.

Part of the trouble seems to have been the natural desire of school examiners to qualify as many school-leavers as possible, but the lack of a nationwide clearinghouse for students has meant that less well-qualified students have secured places in higher education at the expense of others by limiting their ambitions. Meanwhile, universities and colleges have tended to recruit less able students to maintain their numbers.

Closer links between schools and universities are a central part of the new trend in higher education, notably in the proposal that senior school students should have access to facilities in universities. In its new form, the link between school and higher education has practical rather than philosophical goals. It seems to be acknowledged that Soviet schools are poorly equipped for modern education (in computing, for example) as well as for their decreed role of work-education.

Although universities are hardly in better shape, the Central Committee seems to have calculated that the new arrangements under which universities will equip themselves by forming links with industrial enterprises will allow them to discharge their new responsibilities towards the schools.

The reorganization now under way nevertheless leaves many questions unanswered. Allowing for parallel ministries at the republic level, there will remain more than 70 ministries and other bodies with responsibility for education.

No central body has yet come to grips with the question of whether work-orientated ('polytechnic') education is the best preparation for all students embarking on tertiary education.

\section{University reorganization stirs controversy in Germany}

Munich/Köln/Bonn

Conflict is brewing across North RhineWestphalia over a controversial plan to reorientate the universities towards high technology. Students and professors alike have been on the streets protesting against cuts in natural sciences, humanities and education courses. As tempers have risen, the ambitious education policy of the governing Social Democrats has increasingly been called into question.

The northern German Land (state) of North Rhine-Westphalia (NRW) is threatened by financial crisis. Huge budget deficits loom over the Social Democratic (SPD) government, as the region's steel and coal industries are rationalized.

The 'university structure plan 2001' was introduced last year with the aim

\section{Natal court casts out government ruling Oxford}

ThE Natal Supreme Court on 14 March declared the subsidy-linked disciplinary conditions imposed on the University of Natal to be of no force and effect. The conditions were imposed last October by the Minister of Education and Culture in the South African House of Assembly, Piet Clase (see Nature 330, 4; 1987). Mr Justice Page ordered Minister of National Education F.W. de Klerk, to pay the costs.

The Natal case had earlier been adjourned pending the release of the full judgement of the Cape Supreme Court in a similar successful application by the universities of Cape Town and the Western Cape (see Nature 331, 651; 1988). Counsel for the universities had attacked the validity of the conditions on three grounds: (1) their imposition exceeded legal powers; (2) they are so vague that they do not convey what the universities are required to do to avoid non-compliance; and (3) they involve unreasonably oppressive or gratuitous interference with the universities' rights. Mr Justice C.T. Howie ruled that the conditions were invalid on all three grounds. He described the conditions as an "intolerable interference" with a university council's duty to have disciplinary powers administered freely and fairly.

Natal University's principal, Professor P. Booysen, said "I hope the matter will now be allowed to rest there and that the universities of South Africa be allowed to get on with the matter of regulating their own lives and their own communities, in such a way that we can meet our educational objectives". of increasing competitiveness with the rapidly advancing south German Länder by emphasizing university courses in electronics, computer science and other technical fields. At the same time, cuts were proposed in fields where there are already surpluses of graduates.

The ministry has been forced to retreat in areas where student and faculty protests have been intense. For example, NRW Science Minister Anke Brunn announced in January that the physics faculty in Bonn would be "pushed" while physics in nearby Köln would "not necessarily be eliminated". This brought the Köln physicists and their students onto the streets.

Responses to the plan have depended on individual institutions' histories. The four oldest universities - Köln, Bonn and Münster and the Technische Hochschule at Aachen - stand to lose the most. The newest institutions - the Gesamthochschulen in Duisburg, Essen, Paderborn, Siegen and Wuppertal - will almost certainly be protected. The reasons trace back to the ambitious expansion undertaken by the former science minister and now NRW minister-president Johannes Rau (SPD) in the 1970s. The philosophy was to "regionalize" NRW's universities by opening five institutions in new places, in addition to the four universities founded in the 1960s (in Bochum, Düsseldorf, Dortmund and Bielefeld).

The five newcomers have established themselves in useful niches, for example in microelectronics in Duisburg. They have brought economic benefits to previously underdeveloped areas, as in Siegen. The financial costs have been high but the political costs of closing even one of the universities would be even higher. It would be tantamount to admitting that the regionalization policy was a failure.

The greatest threat to the viability of NRW's universities is the expected reduction in the number of students by the mid1990 s, currently estimated at 30 per cent. In order to avoid the humiliation of having to close a Gesamthochschule, the Science Ministry is making every effort to make them more attractive by its restructuring plan.

The Ministry has promised not to make any outright cuts until after the next elections in 1990. But what will happen then? Unhappy at the ministry's autonomy in the restructuring process, a group of researchers have appealed to the Wissenschaftsrat, West Germany's federal science advisory council, for an outside appraisal. The council will decide this summer at the earliest if it wants to make recommendations. It seems likely that it will.

Steven Dickman 